\title{
Polydipsia in Chronic Psychiatric Patients: Therapeutic Trials of Clonidine and Enalapril
}

\author{
Robert M. Greendyke, M.D., Alan J. Bernhardt, Ph.D., Hedy E. Tasbas, M.D.,
} and Kathleen S. Lewandowski, Ph.D.

A six month long double-blind, placebo-controlled, crossover design pharmacological study was conducted on 14 chronically psychotic, institutionalized patients who suffered from chronic water abuse ("psychogenic polydipsia"). Effects of clonidine and enalapril administered separately and individually were assessed for possible beneficial effects on both physiological parameters such as diurnal weight gain, urine output, and serum sodium levels and on signs of delirium as measured by neurobehavioral testing. Improvement, particularly in tests reflecting fluid consumption, was found with either or both drugs in approximately $60 \%$ of test subjects, although no behavioral improvement was demonstrated. As a result of evidence for delayed and carry-over effects the authors recommend that future studies employ phases longer than one month and/or include washout periods. [Neuropsychopharmacology 18:272-281, 1998] (C) 1998 American College of Neuropsychopharmalogy. Published by Elsevier Science Inc.

cle cramps, blurred vision, weakness, tremors, restlessness, confusion, lethargy, delirium, seizures, coma, and death), behavioral and cognitive problems, gastrointestinal symptoms, urinary tract disease (incontinence, hydronephrosis, renal failure), congestive heart failure, and metabolic abnormalities (hypocalcemia, osteopenia).

The fact that the pathophysiology of water intoxication is complex and probably multifactorial (Vieweg et al. 1986a; Vieweg et al. 1988a; Goldman et al. 1988) makes the treatment difficult, inasmuch as particular therapeutic approaches may be beneficial in only certain patients and escape statistical recognition in small studies. Incomplete understanding of why certain patients drink fluids to excess hampers selection of potentially beneficial drugs, a problem compounded by the observation that patients with water intoxication exhibit both polydipsia and impaired water excretion as their disease progresses. Various possible etiologies have been proposed for polydipsia, including hyperactivity of hypothalamic thirst centers, secondary effects of neuroleptic medications, an increase in endogenous opiate receptor effects, and delusions having to do with fluid intake and for hyponatremia and water intoxication, including inappropriate release of the antidiuretic 
hormone, vasopressin (SIADH), and a lowering of the threshold for antidiuretic hormone (ADH) release (or resetting of the hypothalamic osmostat) (Boyd 1990; Crammer 1991; Goldman 1991; Illowsky and Kirch 1988; Patel 1994; Riggs et al. 1991).

Various therapeutic approaches based on these postulated mechanisms have been used with beneficial though limited effects claimed (Vieweg et al. 1985a; Vieweg 1994). Drugs used have included naloxone (Nishikawa et al. 1992), lithium (Khamnei 1984; Raskind and Christopher 1974), lithium plus phenytoin (Vieweg et al. 1988b), demeclocycline (Nixon et al. 1982; Goldman and Luchins 1985; Nixon et al. 1982; Khamnei 1984; Vieweg et al. 1988c), propranolol (Shevitz et al. 1980, Goldstein and Folsom 1991; Kathol et al. 1986), sodium chloride (Vieweg et al. 1985b; Goldman et al. 1994), captopril
(Goldstein 1986; Sebastian and Bernardin 1990; Kathol et al. 1986; Lawson et al. 1988), and enalapril (Sebastian and Bernardin 1990). Clozapine treatment appears particularly promising (Spears et al. 1993; Munn 1993; Lee et al. 1991; Henderson and Goff 1994; Leadbetter et al. 1994; Leadbetter and Shutty 1994; Lyster et al. 1994; DeLeon et al. 1995) (see review by Vieweg et al. 1994). Some successes with behavioral approaches have been reviewed by Vieweg (1993).

\section{METHODS}

Two drugs were chosen for preliminary investigation of possible beneficial effects in chronic water abuse, both selected because they have been implicated in reducing

Table 1. Demographic Data on Study Patients

\begin{tabular}{|c|c|c|c|c|c|c|}
\hline Pt. No. & $\begin{array}{l}\text { Group } \\
\text { Number }\end{array}$ & $\begin{array}{l}\text { Diagnosis } \\
\text { (DSM IV) }\end{array}$ & $\begin{array}{l}\text { Age } \\
\text { (yrs) }\end{array}$ & $\begin{array}{c}\text { Duration of } \\
\text { Psychiatric } \\
\text { Hospitalization } \\
\text { (years) }\end{array}$ & $\begin{array}{c}\text { Estimated } \\
\text { Duration of } \\
\text { Water Abuse } \\
\text { (years) }\end{array}$ & $\begin{array}{c}\text { Current } \\
\text { Medications }\end{array}$ \\
\hline 1 & 3 & chronic schizophrenia & 44 & 12 & $?$ & $\begin{array}{l}\text { haloperidol } \\
\text { lithium } \\
\text { lorazapam }\end{array}$ \\
\hline 2 & 3 & chronic schizophrenia & 67 & 39 & 32 & $\begin{array}{l}\text { carbamazepine } \\
\text { fluphenazine } \\
\text { nortriptyline }\end{array}$ \\
\hline 3 & 3 & chronic schizophrenia & 65 & 15 & 8 & $\begin{array}{l}\text { carbamazepine } \\
\text { risperdol } \\
\text { lorazapam }\end{array}$ \\
\hline 4 & 3 & chronic schizophrenia & 50 & 11 & $?$ & $\begin{array}{l}\text { haloperidol } \\
\text { lithium }\end{array}$ \\
\hline 5 & 1 & chronic schizophrenia & 61 & 21 & 15 & $\begin{array}{l}\text { lithium } \\
\text { risperdol } \\
\text { valproate } \\
\text { lorazapam }\end{array}$ \\
\hline 6 & 1 & chronic schizophrenia & 56 & 8 & 5 & $\begin{array}{l}\text { carbamazepine } \\
\text { risperdol } \\
\text { trazadone } \\
\text { lorazapam }\end{array}$ \\
\hline 7 & 1 & chronic schizophrenia & 43 & 18 & 2 & risperdol \\
\hline 8 & 1 & chronic schizophrenia & 38 & 12 & 5 & $\begin{array}{l}\text { benztropine } \\
\text { risperdol } \\
\text { lorazapam }\end{array}$ \\
\hline 9 & 2 & chronic schizophrenia & 46 & 14 & 8 & $\begin{array}{l}\text { risperdol } \\
\text { trazadone }\end{array}$ \\
\hline 10 & 2 & chronic schizophrenia affective psychosis & 49 & 20 & ? & $\begin{array}{l}\text { carbamazepine } \\
\text { chlorpromazine } \\
\text { lithium }\end{array}$ \\
\hline 11 & 2 & chronic schizophrenia & 31 & 8 & $?$ & $\begin{array}{l}\text { fluphenazine } \\
\text { lithium } \\
\text { trazadone } \\
\text { valproate }\end{array}$ \\
\hline 12 & 2 & post-traumatic psychosis & 44 & 14 & 1 & $\begin{array}{l}\text { carbamazepine } \\
\text { fluphenazine }\end{array}$ \\
\hline 13 & 2 & undifferentiated psychosis & 50 & 29 & 2 & $\begin{array}{l}\text { chlorpromazine } \\
\text { valproate } \\
\text { lorazapam }\end{array}$ \\
\hline 14 & 2 & schizophrenia & 46 & 10 & 4 & risperdol \\
\hline
\end{tabular}


Table 2. Scheme of Drug Administration

\begin{tabular}{lcccccc}
\hline & \multicolumn{7}{c}{ Phases } \\
\cline { 2 - 7 } Patient Group & $\mathbf{1}$ & $\mathbf{2}$ & $\mathbf{3}$ & $\mathbf{4}$ & $\mathbf{5}$ & $\mathbf{6}$ \\
\hline 1 & Placebo $^{a}$ & Placebo & Clonidine & Placebo & Enalapril & Placebo \\
2 & Placebo $^{a}$ & Placebo & Enalapril & Placebo & Clonidine & $\begin{array}{l}\text { Placebo } \\
3\end{array}$ \\
Placebo $^{a}$ & Placebo & Placebo & Clonidine & Placebo & Enalapril \\
\hline
\end{tabular}

${ }^{a}$ Water restriction was used during phase 1 but not thereafter. Experimental design used. All phases were 4 weeks in duration with the exception of phase 2, which was 5 weeks in duration.

water intake: clonidine, an $\alpha$-adrenergic blocking agent, and enalapril, an angiotensin-converting enzyme inhibitor (Sebastian and Bernardin 1990; Crammer 1991; Verghese et al. 1993). Both agents have been widely used for treatment of hypertension. The inpatient psychiatric population of the hospital was surveyed, using a questionnaire administered to head nurses to detect patients in whom water abuse had been observed. A total of 61 patients was identified in a population of 244 . These patients were then visited by two of the authors, their nursing attendants interviewed and their clinical records reviewed to assess the nature and severity of the problem. Patients with specific etiologies for polydipsia were excluded as were those considered too frail to tolerate the drug regimen proposed. Although we appreciated the role that carbamazepine can play in impairing water excretion, it was noted that in three of the five patients receiving the drug, their problem with water abuse antedated its use. Similarly, the five patients being treated with lithium, which may cause a secondary polydipsia, had exhibited water abuse during prolonged periods over the years in which lithium was not given.
Written authorization and consent from 17 male patients and their next of kin were obtained. One patient dropped out of the investigation because of the multiple venipunctures involved. The remaining 16 patients were randomly assigned to three groups (group $1, n=$ 5; group 2, $n=5$, and group $3, n=6$ ). Two patients (one from group 1 and one from group 3) were dropped from the study because they failed to exhibit sufficient evidence of a current problem with excessive water intake during the two initial baseline phases. All 14 of these patients had histories of at least occasional water intoxication in addition to polydipsia. Severity ratings of these patients' water intoxication based upon interviews with staff who were familiar with them placed two in the mild range, seven in the moderate range, and five in the moderate to severe range. Table 1 presents pertinent demographic data on the 14 patients who completed the study. A double-blind, placebo-controlled, crossover design was used as shown in Table 2. Clonidine was administered in a dose of $0.2 \mathrm{mg}$ PO BID and enalapril $10 \mathrm{mg}$ PO BID in single capsules prepared to appear identical to the placebo, which was also administered PO BID. The study

Table 3. Range of Abnormality in Study Patients without Water Restriction but before Experimental Drug Treatment

\begin{tabular}{|c|c|c|c|c|c|c|c|c|c|}
\hline \multirow[b]{3}{*}{ Pt. No. } & \multicolumn{8}{|c|}{ Selected Baseline (Phase 2) Assessment Data } & \\
\hline & \multicolumn{3}{|c|}{ CUO } & \multicolumn{3}{|c|}{ PDWG } & \multicolumn{3}{|c|}{$\mathrm{SNa}$} \\
\hline & Min & Max & Mean & Min & Max & Mean & Min & Max & Mean \\
\hline 1 & 3.3 & 16.4 & 12.5 & -1.3 & 6.1 & 1.4 & 125 & 141 & 136 \\
\hline 2 & 3.9 & 12.2 & 6.1 & -3.0 & 5.1 & 2.0 & 126 & 138 & 133 \\
\hline 3 & 4.3 & 10.4 & 6.5 & -2.9 & 10.4 & 4.5 & 128 & 139 & 132 \\
\hline 4 & 1.0 & 6.8 & 2.0 & -0.7 & 3.8 & 1.3 & 137 & 140 & 138 \\
\hline 5 & 1.8 & 12.5 & 6.5 & -0.3 & 9.3 & 2.9 & 129 & 141 & 138 \\
\hline 6 & 1.3 & 5.8 & 3.7 & -2.5 & 5.1 & 0.6 & 122 & 132 & 127 \\
\hline 7 & 2.9 & 18.7 & 13.7 & -0.9 & 2.1 & 0.4 & 139 & 141 & 141 \\
\hline 8 & 0.7 & 5.2 & 2.3 & -1.9 & 7.0 & 3.4 & 128 & 138 & 134 \\
\hline 9 & 2.0 & 11.1 & 5.8 & -1.1 & 2.9 & 1.0 & 133 & 138 & 135 \\
\hline 10 & 1.2 & 4.74 & 2.5 & 0.3 & 3.7 & 1.8 & 138 & 142 & 140 \\
\hline 11 & 1.4 & 7.6 & 4.4 & -1.1 & 2.8 & 1.0 & 139 & 142 & 141 \\
\hline 12 & 0.8 & 1.7 & 1.1 & 0 & 3.9 & 2.0 & 127 & 137 & 132 \\
\hline 13 & 1.4 & 6.14 & 2.9 & -1.8 & 2.9 & 1.8 & 136 & 139 & 138 \\
\hline 14 & 1.9 & 10.8 & 5.4 & -2.3 & 7.2 & 3.1 & 124 & 138 & 131 \\
\hline
\end{tabular}




\section{A CUO - PLACEBO vs. CLONIDINE}

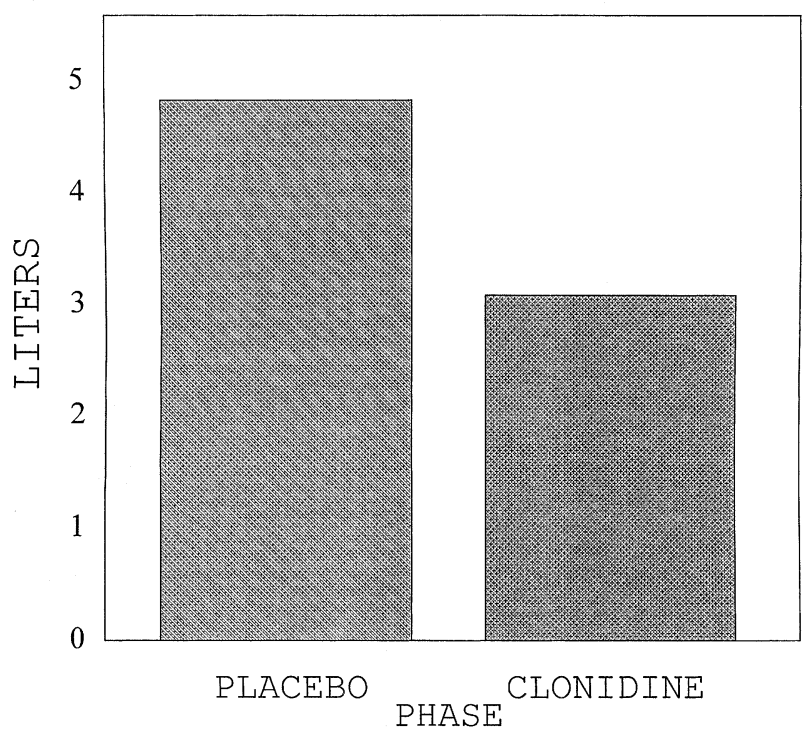

B CUO - PLACEBO vs. ENALAPRIL

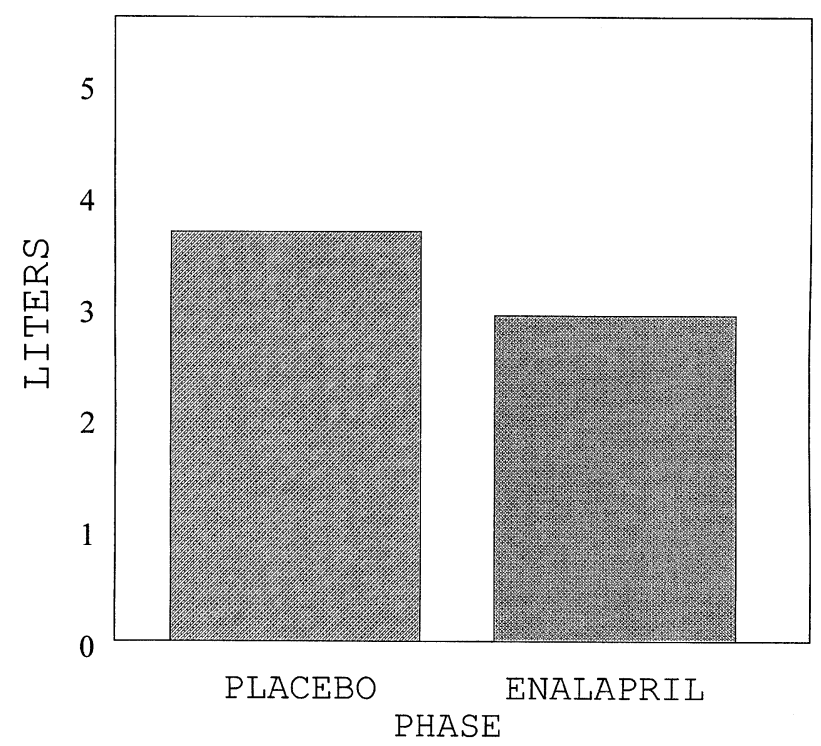

Figure 1. Calculated 24-h urine output in 14 patients treated with placebo, clonidine, and enalapril.

patients were all cohorted in one area of a single hospital floor.

Initial patient assessment included a detailed medical and psychiatric history, repeat physical examination, cognitive testing, electrocardiogram (EKG) and laboratory evaluation, including complete blood count (CBC), serum electrolytes, glucose, liver function tests, $\mathrm{T} 4$, and urinalysis. Current medications (see Table 1) were maintained unchanged throughout the 6 months of the study. Any fluid restriction being imposed on the study patients was terminated after 1 month except for emergency situations. Assessment measures included: twice daily determinations of body weight (6:00 A.M. and 7:00 P.M.), vital signs TID for week 1 of each experimental phase and QD thereafter, determination of serum sodium, creatinine and osmolality plus urine osmolality and creatinine twice a week (3:00 P.M. Tuesday and Friday) and weekly CBC. Behavioral and cognitive functioning were assessed using the Nursing Observation Scale for Inpatient Evaluation (NOSIE) (administered by the same nurses on

Table 4. Changes in Dependent Variables in Individual Subjects with Drug Treatment

\begin{tabular}{|c|c|c|c|c|c|c|c|c|c|c|c|c|c|c|c|}
\hline \multirow{2}{*}{$\begin{array}{l}\text { Positive } \\
\text { Response } \\
\text { to: }\end{array}$} & \multirow{2}{*}{$\begin{array}{c}\text { Pt. } \\
\text { No. }\end{array}$} & \multicolumn{7}{|c|}{ Clonidine } & \multicolumn{7}{|c|}{ Enalapril } \\
\hline & & CUO & UOSM & $\mathrm{SNa}$ & WGP & NOSIE & BPRS & BCOG & CUO & UOSM & $\mathrm{SNa}$ & DWGP & NOSIE & BPRS & BCOG \\
\hline \multirow{3}{*}{$\begin{array}{l}\text { Clonidine } \\
\text { and } \\
\text { enalapril }\end{array}$} & 2 & $42^{\circ}$ & $29 \%$ & 0.8 & $-14 \%$ & $-6 \%$ & $-16 \%$ & $-5 \%$ & $41 \%$ & $47 \%$ & -1.1 & $40 \%$ & & $19 \%$ & $-30^{\circ}$ \\
\hline & 3 & $55 \%$ & $125 \%$ & 1.9 & $122 \%$ & $24 \%$ & $4 \%$ & $-20 \%$ & $45 \%$ & $51 \%$ & -3.3 & $50 \%$ & $-13 \%$ & $5 \%$ & $75^{\circ}$ \\
\hline & 7 & $75 \%$ & $261 \%$ & -0.4 & $-80 \%$ & $-9 \%$ & $3 \%$ & $-19 \%$ & $63 \%$ & $24 \%$ & -0.9 & $15 \%$ & $-4 \%$ & $14 \%$ & $-8^{\circ}$ \\
\hline \multirow{4}{*}{$\begin{array}{l}\text { Clonidine } \\
\text { only }\end{array}$} & 1 & $45 \%$ & U & 0.2 & $-54 \%$ & $24 / 0$ & $14 \%$ & $1 \%$ & $1 \%$ & $-40 \%$ & -3.5 & $-1 \%$ & $28 \%$ & $-2 \%$ & \\
\hline & 8 & $49 \%$ & $15 \%$ & 2.5 & $36 \%$ & $-14 \%$ & $-8 \%$ & $-22 \%$ & $-56 \%$ & $4 \%$ & -1.2 & $-45 \%$ & $-4 \%$ & $-6 \%$ & $-31 \%$ \\
\hline & 10 & $39 \%$ & $76 \%$ & -0.4 & $30 \%$ & $-3 \%$ & $-7 \%$ & $-4 \%$ & $-17 \%$ & $-34 \%$ & -2.3 & $-18 \%$ & $-4 \%$ & $5 \%$ & $-4^{\circ}$ \\
\hline & 13 & $46 \%$ & $31 \%$ & 0.3 & $-54 \%$ & $1 \%$ & $-22 \%$ & $-17 \%$ & $14 \%$ & $-21 \%$ & -1.0 & $19 \%$ & $-12 \%$ & $25 \%$ & -17 \\
\hline \multirow{2}{*}{$\begin{array}{l}\text { Enalapril } \\
\text { only }\end{array}$} & 6 & & $-31 \%$ & -0.6 & & $26 \%$ & & & & & -0.7 & & $-3 \%$ & $12 \%$ & -11 \\
\hline & 9 & $9 \%$ & $32 \%$ & 0.8 & $-34 \%$ & $17 \%$ & $-2 \%$ & $50 \%$ & $57 \%$ & $57 \%$ & 0.5 & $-16 \%$ & $14 \%$ & $-25 \%$ & 50 \\
\hline \multirow{5}{*}{$\begin{array}{l}\text { Neither } \\
\text { drug }\end{array}$} & 4 & $-24 \%$ & $-11 \%$ & 0.0 & $-36 \%$ & $-6 \%$ & $-20 \%$ & $-17 \%$ & $0 \%$ & $13 \%$ & -1.1 & $5 \%$ & $3 \%$ & $7 \%$ & -2 \\
\hline & 5 & $16 \%$ & $-4 \%$ & 0.4 & $59 \%$ & $8 \%$ & $13 \%$ & $125 \%$ & $18 \%$ & $9 \%$ & 0.4 & $28 \%$ & $-4 \%$ & $1 \%$ & -42 \\
\hline & 11 & $-13 \%$ & $11 \%$ & -0.9 & $-11 \%$ & $0 \%$ & $-6 \%$ & $8 \%$ & $20 \%$ & $-25 \%$ & -0.1 & $-12 \%$ & $-8 \%$ & $11 \%$ & \\
\hline & 12 & $-96 \%$ & $26 \%$ & -3.1 & $-38 \%$ & $6 \%$ & $4 \%$ & $-6 \%$ & $-76 \%$ & $-42 \%$ & -2.5 & $50 \%$ & $-2 \%$ & $3 \%$ & -6 \\
\hline & 14 & $-10 \%$ & $26 \%$ & 4.7 & $12 \%$ & $19 \%$ & $6 \%$ & $-38 \%$ & $34 \%$ & $-3 \%$ & -1.4 & $69 \%$ & $-25 \%$ & $15 \%$ & -38 \\
\hline
\end{tabular}

All cells show percent improvement during drug phase compared with previous placebo phase except serum sodium, where improvement is expressed as positive change in absolute value. 

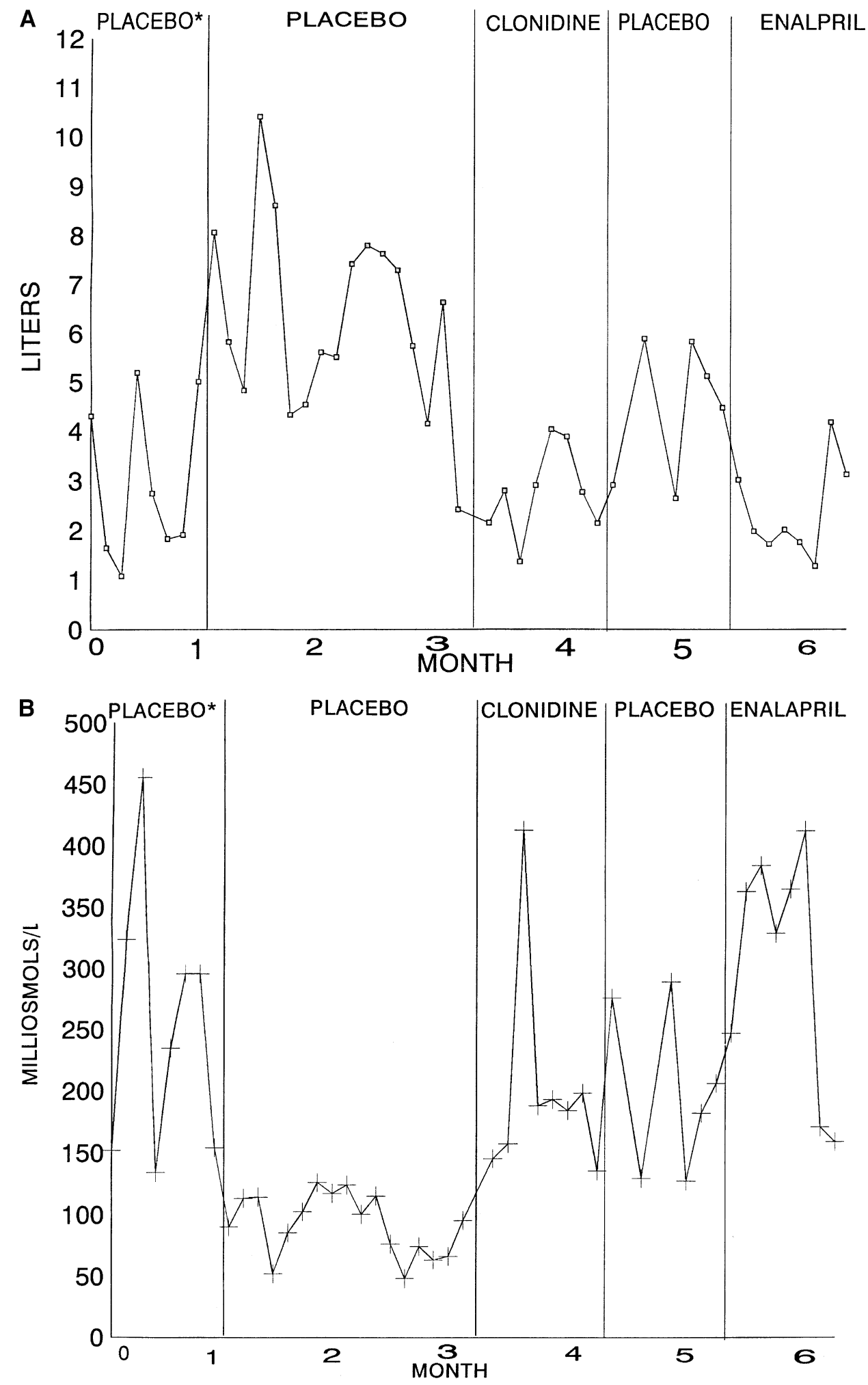

Figure 2. Selected results on one of the study patients (patient \#3): (A) Calculated urine output (L/24 h); (B) 3:00 P.M. urine osmolality (mOsM/ $\mathrm{L})$; (C) Serum sodium (mEq/ L); (D) 8:00 A.M. to 3:00 P.M. weight gain (lb). *Placebo plus water restriction. Free access to fluids was permitted throughout subsequent phases.

the same patients once per week), the Brief Psychiatric Rating Scale (BPRS) (administered once weekly by one of the psychiatrist authors, and a clinical nurse specialist) and brief psychological testing, comprising elements of the Mini-Mental state examination, Benton Temporal
Orientation, and the Digit Span subscale (multiple forms) of the WAIS-R, administered weekly by one of the psychologist authors, and a psychology assistant.

Because of the patients' inability to cooperate, traditional intake and output records could not be main- 

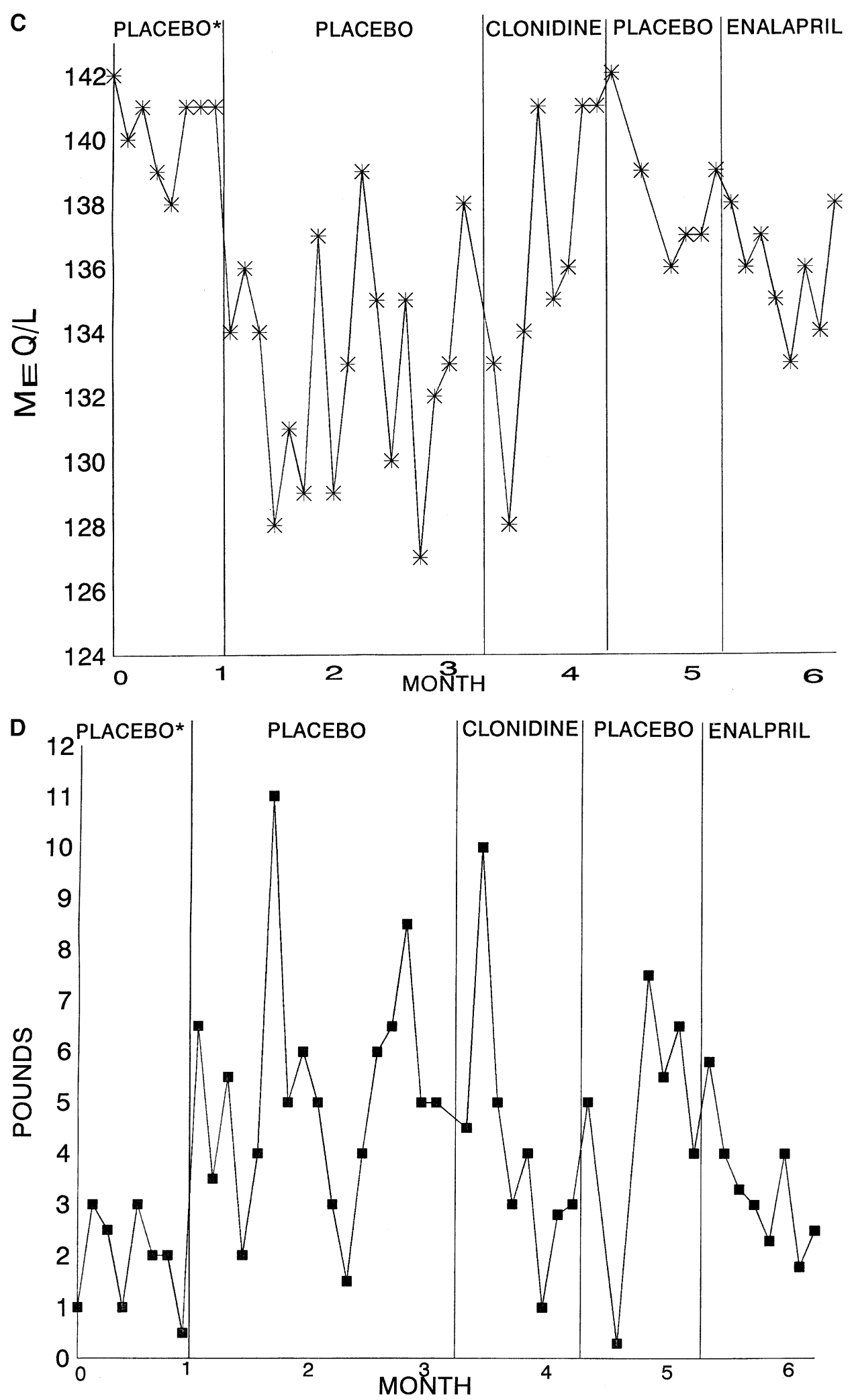

Figure 2. Continued.

tained, and surrogate measures were used as described by previous authors (Vieweg et al. 1992). Thus, diurnal weight gain provided a crude minimum estimate of fluid consumption or more specifically fluid retention in excess of excretion (Vieweg et al. 1988a, b, c, 1989a, b, c, 1990). Calculated urine output (CUO) was based upon the work of Vieweg et al. (1986b, 1988a, 1992), using expected 24 -h creatinine production and urine creatinine levels to calculate predicted excretion. Table 3 shows selected baseline (phase 2) assessment data. 

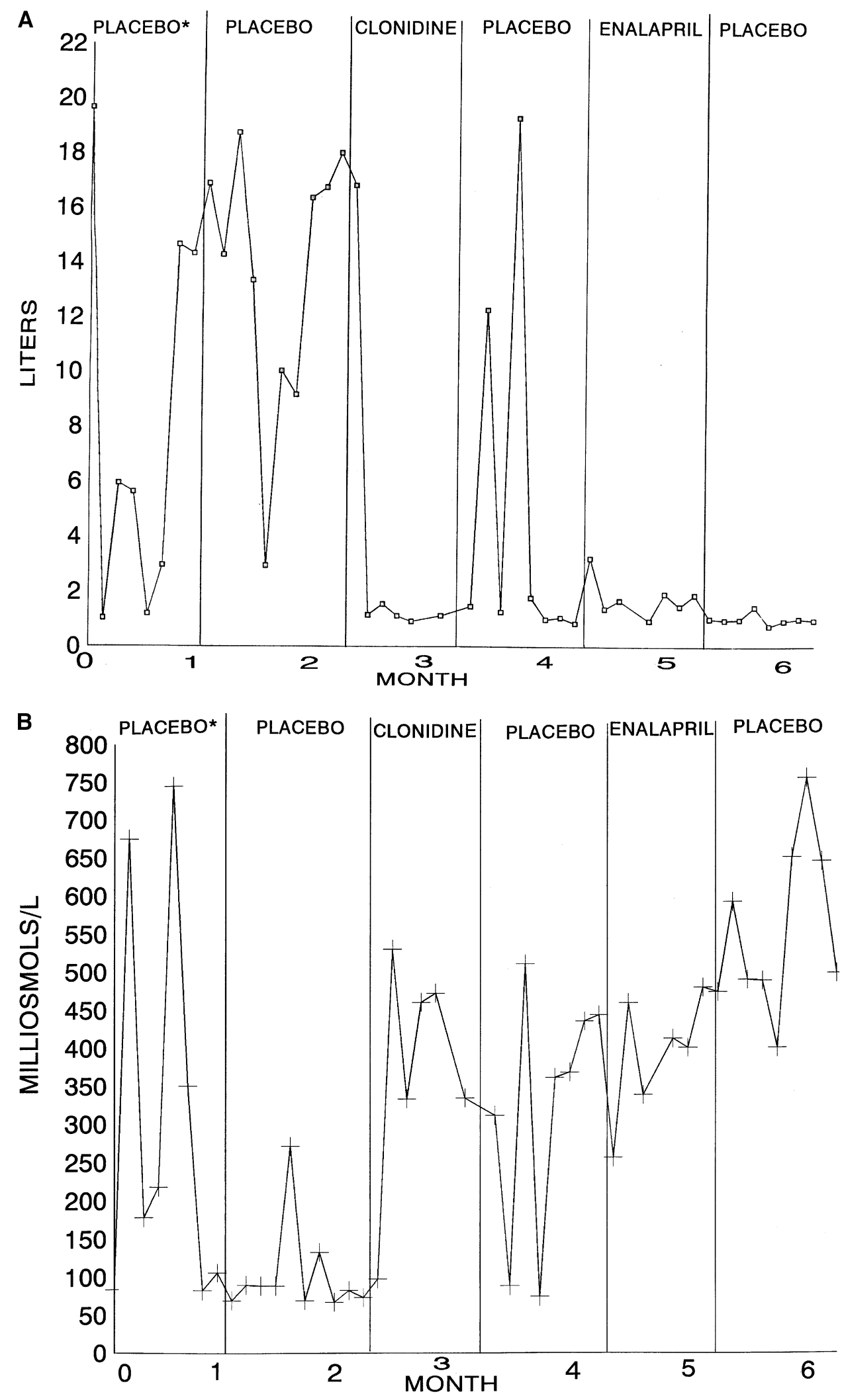

Figure 3. Selected results on one of the study patients $\left({ }^{*} \# 7\right)$ : (A) Calculated urine output (L/24 h); (B) 3:00 P.M. urine osmolality (mOsM/L). *Placebo plus water restriction. Free access to fluids was permitted throughout subsequent phases.

\section{RESULTS}

The outcome measures used to assess possible drug effects can be conveniently grouped as biological changes, including calculated urine output (CUO), urine osmolality (UOSM), serum sodium (SNa), and percentage diurnal weight gain (PDWG), plus secondary psychiatric or neurobehavioral changes as measured by the NOSIE, 
BPRS, and brief cognitive testing (BCOG). The results of group-statistical analyses conducted are reported first, followed by a detailed examination of individual subject's responses to the two experimental medications.

One tailed $t$-tests for correlated measures, comparing subjects' mean scores during phase 1, the first baseline phase, to phase 2, the second baseline phase, resulted in significant $p$ values showing adverse effects of subjects' free access to water after a month of water restriction on all four biological variables, including CUO $(p<.001)$, UOSM $(p<.001)$, SNa $(p<.05)$, and PDWG $(p<.05)$. Similar comparisons on the three behavioral measures failed to yield significant results.

One tailed $t$-tests for correlated measures found CUO to be significantly lower $(p<.05)$ and UOSM to be significantly higher $(p<.01)$ during the clonidine phase than the preceding placebo phase. T-tests comparing the enalapril treatment phase with the preceding baseline phase yielded a significant difference in the same (predicted) direction for CUO $(p<.01)$ only. Comparisons on all other dependent variables failed to yield significant results. These tests used an $n$ of 14 (collapsing across groups), because the counterbalanced design of the study controlled for order effects. Mean CUOs for drug versus placebo phases are depicted graphically in Figure 1.

Based upon the magnitude of the percentage of change in the predicted direction on the two measures most directly affected by excessive drinking, CUO and UOSM, the authors classified subjects as being "responders" or "nonresponders" to the two experimental drugs. The criteria for judging a subject to be a "responder" was that he showed a mean decrease on CUO and increase on UOSM of $30 \%$ or more. These data are summarized in Table 4, where it will be seen that, of the 14 patients who participated in the study, three responded well biologically to both drug treatments (improvement in CUO and UOSM), four responded favorably to clonidine only, two responded favorably to enalapril only, and five showed no clear evidence of benefit from either drug.

Figure 2 depicts data from a patient (\#3 in Tables 1 and 3) who responded favorably to both drug treatments across all four biochemical measures (CUO, UOSM, SNa, and PDWG). With the exception of SNa values during the enalapril phase, all the other data show evidence of favorable changes during experimental drug phases and reversals during the placebo phase after the initial drug phase (ABAC). The U-shape of the curve connecting $\mathrm{SNa}$ values during the enalapril phase would be consistent with a delayed effect of enalapril. Behavioral measures showed no consistent pattern of change following introduction of drugs for this subject.

Figure 3 depicts data from another patient (\#7 in Tables 1 and 3), who showed a reversal of his CUO and UOSM values in the predicted direction after the introduction of both clonidine and enalapril, providing strong evidence of an effect of the experimental medications on his fluid intake. Unlike the previous subject, however, patient \#7 did not show any favorable change in SNa or PDWG nor on any of the behavioral measures. A possible explanation for the difference between this subject's data and the previously discussed subject is discussed below.

Both subjects \#3 and \#7 above showed some evidence of delayed and prolonged effects of the experimental treatments. Similar evidence of delayed effects (ranging from 3 to 14 days) and prolonged effects (ranging from 1 to 4 weeks) was seen in over half of the patients who responded to drug treatment.

\section{DISCUSSION}

The results of this study suggest that drugs known to affect body water balance may diminish excess water intake in some patients with histories of water abuse. Indirect measures of fluid intake (CUO and UOSM) were beneficially affected by both clonidine and enalapril in some subjects. In fact, $60 \%$ of our study group clearly improved (using the criteria of a mean change of $30 \%$ or greater in the predicted directions for both CUO and UOSM), and a few subjects showed associated changes in serum sodium and percentage diurnal weight gain, while on even a brief trial of clonidine or enalapril. These numbers might be greater if trials were prolonged. Individual data presented on two subjects, demonstrated a direct effect of clonidine and enalapril on both CUO and UOSM in the predicted direction during both treatment and placebo phases. Individual data also illustrated a time lag after initial response to drug treatment as well as effects enduring as long as a month after drug treatment. As a result of evidence for carryover effects of both fluid restriction and the study drugs on fluid intake, it is recommended that future studies use longer washout periods after drug and water restriction phases. Similarly, due to delayed effects, it may be useful to use longer drug phases also.

Finally, the data showed inconsistent changes in $\mathrm{SNa}$ and PDWG. Subject \#3, for example, showed changes in these measures during the experimental phases, whereas subject \#7 did not. Likewise, there was no consistent improvement in behavior or cognition in study patients during treatment phases. These findings may be explained by the fact that many subjects, in spite of their history of polydipsia, still had adequate renal function and therefore might not be expected to show changes in $\mathrm{SNa}$ or PDWG with excess fluid intake. Changes in those measures would occur only in patients who retain the excess water. It is postulated that many of the subjects still had good kidney function and did not retain fluid volume abnormally. The failure to achieve greater therapeutic effects could also be a consequence of the 
relatively brief duration of the treatment phases. In most of our patients, water abuse was of prolonged duration (see Table 1) with changes unlikely to be reversed within the space of a single month of treatment. Although further studies will be required to replicate our findings, the initial data suggest that results comparable to water restriction may be obtainable through medication. We urge that future studies in this area use appropriate placebo controls and crossover designs with statistical analysis to allow more sophisticated evaluation of potentially beneficial drugs than has been possible with previously published work.

\section{ACKNOWLEDGMENTS}

The following persons are gratefully acknowledged for their many hours of dedicated work on this study: Betty Adams, R.N., Susan Green, R.N., Joanne Healy, R.N., M.A., C.S., Janet Kulnot, R.N., Mariane Lennon, R.N., Valorie Lombardo, R.N.C., and Bonnie White, B.A.

\section{REFERENCES}

Boyd, MA (1990): Polydipsia in the chronically mentally ill: A review. Arch Psychiatric Nurs 4:166-175

Crammer JL (1991): Drinking, thirst and water intoxication. Br J Psychiatry 159:83-89

DeLeon J, Verghese C, Tracy JI, Josiassen RC, Simpson GM (1994): Polydipsia and water intoxication in psychiatric patients: A review of the epidemiological literature. Biol Psychiatry 35:408-419

DeLeon J, Verghese C, Stanilla JK, Lawrence T, Simpson GM (1995): Treatment of polydipsia and hyponatremia in psychiatric patients: Can clozapine be a new option? Neuropsychopharmacology 12:133-138

Goldman MB, Luchins DJ (1985): Demeclocycline improves hyponatremia in chronic schizophrenics. Biol Psychiatry 20:1149-1155

Goldman MB, Luchins DJ, Robertson GL (1988): Mechanisms of altered water metabolism in psychotic patients with polydipsia and hyponatremia. N Engl J Med 318:397-403

Goldman MB (1991): A rational approach to disorders of water balance in psychiatric patients. Hosp Community Psychiatry 42:488-494

Goldman MB, Nash M, Blake L, Petkovic MS (1994): Do electrolyte-containing beverages improve water imbalance in hyponatremic schizophrenics? J Clin Psychiatry 55:151-153

Goldstein JA (1986): Captopril in the treatment of psychogenic polydipsia (letter). J Clin Psychiatry 47:99

Goldstein JA, Folsom T (1991): The successful treatment of psychogenic polydipsia and water intoxication with propranolol. Minn Med 74:29-32

Henderson DC, Goff DC (1994): Clozapine for polydipsia and hyponatremia in chronic schizophrenics. Biol Psychiatry $36: 768-770$
Illowsky BP, Kirch DG (1988): Polydipsia and hyponatremia in psychiatric patients. Am J Psychiatry 145:675-683

Kathol EG, Wilcox JA, Turner RD, Kranfol Z, Olson SC (1986): Pharmacologic approaches to psychogenic polydipsia: Case reports. Prog Neuro-Psychopharmacol \& Biol Psychiatry 10:95-100

Khamnei AK (1984): Psychosis, inappropriate anti-diuretic hormone secretion and water intoxication. Lancet 1:963

Lawson WB, Williams B, Pasion E (1988): Effects of captopril on psychosis and disturbed water regulation. Psychopharmacol Bull 24:176-178

Leadbetter RA, Shutty MS, Higgins PB, Pavalonis D (1994): Multidisciplinary approach to psychosis, intermittent hyponatremia and polydipsia. Schizophr Bull 20:375-385

Leadbetter RA, Shutty MS (1994): Differential effects of neuroleptics and clozapine on polydipsia and intermittent hyponatremia. J Clin Psychiatry 55:110-113

Lee HS, Kwon KY, Alphus LD, Meltzer NY (1991): Effect of clozapine on psychogenic polydipsia in chronic schizophrenia. J Clin Psychopharmacol 11:222-223

Lyster C, Miller AL, Seidel D, Kavanagh J (1994): Polydipsia and clozapine (letter). Hosp Community Psychiatry 45:610-611

Munn NA (1993): Resolution of polydipsia and hyponatremia in schizophrenic patients after clozapine treatment. J Clin Psychiatry 54:439-440

Nishikawa T, Tsuda A, Tanaka M, Nishidawa M, Koga I, Uchida Y (1992): Naloxone attenuates drinking behavior in a schizophrenic patient displaying self-induced water intoxication. Clin Neuropharmacol 4:310-314

Nixon RA, Rothman JS, Chin W (1982): Demeclocycline in the prophylaxis of self-induced water intoxication. Am J Psychiatry 139:828-830

Patel JK (1994): Polydipsia, hyponatremia, and water intoxication among psychiatric patients. Hosp Community Psychiatry 45:1073-1074

Raskind MA, Christopher TG (1974): Water intoxication and psychosis (letter). Am Inst Med 80:280

Riggs AT, Dysken MW, Kim SW, Opsahl JA (1991): A review of disorders of water homeostasis in psychiatric patients. Psychosomatics 32:133-148

Sebastian CS, Bernardin AS (1990): Comparison of enalapril and captopril in the management of self-induced water intoxication. Biol Psychiatry 27:787-790

Shevitz SA, Jameison RC, Petrie WM, Crook JE (1980): Compulsive water drinking treated with high dose propranolol. J Nerv Ment Dis 168:246-248

Spears NM, Leadbetter RA, Shutty M (1993): Influences of clozapine on water dysregulation (letter). Am J Psychiatry 150:9

Verghese C, DeLeon J, Simpson GM (1993): Neuroendocrine factors influencing polydypsia in psychiatric patients: An hypothesis. Neuropsychopharmacology 9:157-166

Vieweg WVR (1993): Behavioral approaches in polydipsia. Biol Psychiatry 34:135-137

Vieweg WVR (1994): Treatment strategies in the polydipsiahyponatremia syndrome. J Clin Psychiatry 55:154-160

Vieweg WVR, Rowe WT, David JJ, Spradlin W. (1985a): Oral 
sodium chloride in the management of schizophrenic patients with self-induced water intoxication. J Clin Psychiatry 141:46:16-19

Vieweg WVR, David JJ, Rowe WT, Peach MJ, Veldhuis JD, Kaiser DL, Spradlin WW (1985b): Psychogenic polydipsia and water intoxication-concepts that have failed. Biol Psychiatry 20:1308-1320

Vieweg WVR, Rowe WT, David JJ, Curnow, RT, Spradlin WW (1986a): Self-induced water intoxication and psychosis (SIWIP): Subcategory of the syndrome of inappropriate antidiuresis (SIAD). Psychiatr Med 4:277-290

Vieweg WVR, David JJ, Rowe WT, Yank GR, Spradlin WW (1986b): Diurnal variation of urinary excretion for patients with psychosis, intermittent hyponatremia, and polydipsia (PIP syndrome). Biol Psychiatry 21:1031-1042

Vieweg WVR, Robertson GL, Godleski LS, Yank GR (1988a): Diurnal variation in water homeostasis among schizophrenic patients subject to water intoxication. Schizophr Res 1:351-357

Vieweg WVR, Weiss NM, David JJ, Rowe WT, Veldhuis JD, Kaiser DL, Spradlin WW (1988b): Treatment of psychosis, intermittent hyponatremia, and polydipsia (PIP syndrome) with lithium and phenytoin. Biol Psychiatry 23:25-30

Vieweg WVR, Wilkinson EC, David JJ, Rowe WT, Hobbs WR, Spradlin WW (1988c): The use of demeclocycline in the treatment of patients with psychosis, intermittent hyponatremia, and polydipsia (PIP syndrome). Psychiatr Q 59:62-68
Vieweg WVR, David JJ, Rowe WT, Peach MJ, Veldhuis JD, Kaiser DL, Spradlin WW (1988d): Correlation of parameters of urinary excretion with serum osmolality among patients with psychosis, intermittent hyponatremia, and polydipsia. Psychiatr Med 6:81-97

Vieweg WVR, Godleski LS, Graham P, Kellogg E, Goldman F, Barber J, Bayliss EV, Glick J, Hundley PL, Yank GR (1989a): Diurnal weight gain in chronic psychosis. Schizophr Bull 15:501-506

Vieweg WVR, Godleski LS, Hundley PL, Yank GR (1989b): Survey of diurnal weight gain and urine volume in chronic schizophrenia. Can J Psychiatry 34:779-784

Vieweg WVR, Godleski LS, Mitchell M, Hundley PL, Yank GR (1989c): Abnormal diurnal weight gain among chronically psychotic patients contrasted with acutely psychotic patients and normals. Psychol Med 19:105-109

Vieweg WVR, Godleski LS, Graham P, Barber J, Goldman F, Kellogg E, Bayliss EV, Glick J, Hundley PL, Yank GR (1990): Abnormal diurnal weight gain among institutionalized patients with manic-depressive spectrum disorders. Psychiatr Med 8:129-134

Vieweg WVR, Pandurangi AK, Pelonero AL (1992): Estimating daily urine volume in chronic psychosis. Biol Psychiatry 36:768-770

Vieweg WVR, Pandurangi A, Levenson J, Silverman J (1994): The consulting psychiatrist and the polydipsia-hyponatremia syndrome in schizophrenia. Int J Psychiatry Med 24:275-303 